\title{
Acidity, Vollatyl Fatty Acid and Digestibility In- Vitro of Corn Straw Silage as Energy Source
}

\author{
A. A. A. S. Trisnadewi ${ }^{1}$, I G. L. O. Cakra ${ }^{2}$, I W. Suarna ${ }^{3}$ \\ ${ }^{1}$ Laboratory of Feed Plant, Faculty of Animal Husbandry, Udayana University, Bali, Indonesia \\ Email: aaas_trisnadewi@unud.ac.id \\ ${ }^{2}$ Laboratory of Animal Nutrition, Faculty of Animal Husbandry, Udayana University, Bali, Indonesia \\ Email: oka_cakra@unud.ac.id \\ ${ }^{3}$ Laboratory of Feed Plant, Faculty of Animal Husbandry, Udayana University, Bali, Indonesia \\ Email: wynsuarna@unud.ac.id
}

\begin{abstract}
The research aims to determine the best silage formulation using pollard and molasses to acidity $(\mathrm{pH})$, vollatyl fatty acid, and in vitro digestibility. The experiment use completely randomized design (CRD) with four treatments and four times replication, so it has 16 units experiment. The four treatments are treatment $A=$ $100 \%$ corn straw $+20 \%$ pollard $+0 \%$ molases; $B=$ $100 \%$ corn straw $+10 \%$ pollard $+10 \%$ molases; $C=$ $100 \%$ corn straw $+0 \%$ pollard $+20 \%$ molases; $D=$ $100 \%$ corn straw $+10 \%$ pollard $+0 \%$ molases; $E=$ $100 \%$ corn straw $+5 \%$ pollard $+5 \%$ molases; dan $F=$ $100 \%$ corn straw $+10 \%$ pollard $+0 \%$ molases. Variables observe are $\mathrm{pH}$, vollatyl fatty acid, and in vitro digestibility in rumen fluid including dry matter, and organic matter digestibility. Results of the experiment showed that nutrient content and acidity on treatment $A$ is highest. Level of VFA total, dry matter digestibility, organic matter digestibility are significant different $(P<0,05)$. Microbes need energy and protein for the growth and could be fullfill from corn straw silage that combination of pollard and molases. It could be concluded that combination of $10 \%$ pollard and $10 \%$ molases could use by microbes to fullfill the need of energy and protein.
\end{abstract}

Keywords - corn straw silage, $\mathrm{pH}$, in vitro digestibility, VFA.

\section{INTRODUCTION}

Ruminant need forage as main energy and protein source, beside consentrate as feed supplement. Feed that usually give to ruminant are grass, leguminose and tree such as Kibatalia arborea and Hibiscus tiliaceus. The availability of forage especially grass is fluctuated where it will be abundant during rainy season but the availability is limmited even deficiency during draught season.

Utilization of waste of agricultural crop resources as a feed source is an efficient step to overcome the lack of grass production. Agricultural waste including an in-situ forage source is available in abundance and easily available. Most of the agricultural waste can be used for cattle feed. The great potential of agricultural waste as a source of forage is corn straw (BPTP West Sumatra, 2011).

Corn is an agricultural commodity that is quite widely developed by farmers in Indonesia. According to Kushartono and Iriani (2003), if the high yield of corn crops can be developed in Indonesia, it is hoped that corn crops can contribute to the provision of forage beside grass, leguminous and rice straw. One of the factors causing underdevelopment of corn crop as livestock feed in Indonesia is the limited of farmer for its utilization. Therefore it is necessary to conduct an economical assessment and development of corn crops more intensive and more introducing how to grow crops and utilization of corn crops as a source of feed.

Plant sugars are fermented by anaerobic bacteria to organic acids which reduce the $\mathrm{pH}$ of the plant material. This process preserves the crop during long-term storage. High quality corn silage results when lactic acid is the predominant acid produced during fermentation. Lactic acid is the most efficient fermentation acid and will drop the $\mathrm{pH}$ of the silage the fastest (University of Wisconsin, 2017).

The principle of silage making is to maintain airtight conditions in silo to the maximum extent possible. Airtight conditions can be pursued by solidification of silage material as much as possible and the addition of fermentable carbohydrate sources (Hidayat and Indrasanti, 2011).

The advantage of silage making are stabile composition of the feed (silage) for a longer period (up to 5 years, plants can be harvested at optimal phase of development and are efficiently used by livestock, and reduction of nutrient loses (Food and Agriculture Organization of United Nation and USAID)

Retnani et al. (2009) study using field grass, corn leaves and corn cloves made biscuits found that $50 \%$ of field grass and $50 \%$ of corn leaves have the lowest water content and water absorption. Waste corn biscuits can be used as a substitute for the source of fiber for sheep 
because it has the same palatability as the field grass biscuits.

Bahri (2012) study using field grass and complete ration diets based on corn straw for 6 weeks showed that a complete silage ration treatment based on corn straw and field grass with 60\%: $40 \%$ ratio showed a better response than other rations on consumption rations and weight gain of bali cattle.

The objective of this study was to obtain a formulation of corn silage using pollard and molasses on $\mathrm{pH}$, vollatyl faty acid, in vitro digestibility.

\section{MATERIALS AND METHODS}

\section{Materials}

The materials used in making corn silage straw are corn straw, pollard, and molasses. Tools used include knives for cutting corn straw, board as cutting pad, plastic sheet to mix silage, plastic bag, and bucket as silo.

\section{Methods}

The research was conducted at Animal Nutrition Laboratory of Faculty Animal Husbandry Udayana University and Ciawi Bogor Livestock Research Laboratory for 3 months from preparation until end of research

Corn straw is cut into $3-5 \mathrm{~cm}$, and mix with pollard, and molasses as per treatment. Then put in a plastic bag, pressed and compressed until there is no air in the plastic bag to create anaerobic state. Then tied tightly and kept in a cool place and not exposed to the sun. Laboratory analysis was conducted after 21 days of fermentation.

The design used in this study was a completely randomized design with six treatments and four replications, so there were 24 experimental units. The six treatments were: $\mathrm{A}=100 \%$ corn straw $+20 \%$ additive $(20 \%$ pollard $+0 \%$ molases $) ; \mathrm{B}=100 \%$ corn straw $+20 \%$ additive $(10 \%$ pollard $+10 \%$ molasses $) ; \mathrm{C}=100 \%$ corn straw $+20 \%$ additives $(0 \%$ pollard $+20 \%$ molasses $) ; \mathrm{D}=$ $100 \%$ corn straw $+10 \%$ additive $(10 \%$ pollard $+0 \%$ molases $) ; \mathrm{E}=100 \%$ corn straw $+10 \%$ additive $(5 \%$ pollard $+5 \%$ molasses $) ; \mathrm{F}=100 \%$ corn straw $+10 \%$ additive $(0 \%$ pollard $+10 \%$ molases $)$.
Variables observed were $\mathrm{pH}$ (acidity), the digestibility of dry matter and organic matter in rumen fluid in-vitro, and Vollatyl Fatty Acid (VFA).

The data obtained in this study were analyzed by using variance analize, if the average value of treatment significantly affected the variables followed by Duncan test at 5\% (Steel and Torrie, 1991).

\section{RESULTS AND DISCUSSION}

Acidity ( $\mathrm{pH}$ value) silage of corn straw silage showed a tendency decreases with decreased pollard supplementation and increased molasses in $20 \%$ supplementation in treatments $\mathrm{A}, \mathrm{B}$, and $\mathrm{C}$ and $10 \%$ in treatment D, E, and F. This indicated that the type (pollard and molasses) and the amount of additives used will affect the quality of silage. The $\mathrm{pH}$ value of the research results ranged from 3.88-4.22 and according to the Agricultural Departement (1980) is very good criteria. The lower the $\mathrm{pH}$ value or the more acidic the silage, the better of silage quality. The use of molasses can decrease the $\mathrm{pH}$ due to molasses as a soluble carbohydrate source which will form a higher lactic acid compared with pollard. The $\mathrm{pH}$ value in the supplementary ingredients with different levels it is seen that the use of additives $10 \%, \mathrm{pH}$ value is more alkaline compared to $20 \%$ because the amount of additive very decisive the formation of lactic acid from lactic acid bacteria. Microbial growth will be higher in silage containing more additives than with the use of lower additives.

$\mathrm{pH}$ value of corn straw silage in treatment $\mathrm{A}$ is higher compared with treatment $\mathrm{B}$ and $\mathrm{C}$ because the $\mathrm{pH}$ value is influenced by the content of VFA and NH3. Silage of corn straw in treatment A has the lowest total VFA content so that the $\mathrm{pH}$ value becomes high because the higher the VFA content, so the lower $\mathrm{pH}$ value or will be acid. The low VFA total content of corn straw silage in treatment A is caused by the utilization of VFA by microbes in the presence of NH-3 availability of the pollard protein, so that microbial proteins are formed and after death will be able to increase the silage protein content.

Tabel.1: Acidity ( $\mathrm{pH}$ value) and Volattile Fatty Acid (VFA) of corn straw silage

\begin{tabular}{lccccccc}
\hline \multirow{2}{*}{ Variables } & \multicolumn{9}{c}{ Treatments $^{\mathbf{1}}$} & \multirow{2}{*}{ SEM $^{\mathbf{2})}$} \\
\cline { 2 - 6 } & $\mathbf{A}$ & $\mathbf{B}$ & $\mathbf{C}$ & $\mathbf{D}$ & $\mathbf{E}$ & $\mathbf{F}$ & \\
\hline Acidity (pH value) & $4,18^{\mathrm{d} 3)}$ & $3,95^{\mathrm{b}}$ & $3,90^{\mathrm{a}}$ & $4,22^{\mathrm{e}}$ & $4,01^{\mathrm{c}}$ & $3,88^{\mathrm{a}}$ & 0,01 \\
VFA partial: & & & & & & & \\
Acetic acid (mM) & $16,35^{\mathrm{b}}$ & $25,02^{\mathrm{c}}$ & $25,22^{\mathrm{c}}$ & $22,38^{\mathrm{c}}$ & $10,04^{\mathrm{a}}$ & $6,93^{\mathrm{a}}$ & 1,98 \\
Propionic acid (mM) & $0,74^{\mathrm{a}}$ & $0,45^{\mathrm{a}}$ & $0,21^{\mathrm{a}}$ & $0,24^{\mathrm{a}}$ & $0,08^{\mathrm{a}}$ & $0,05^{\mathrm{a}}$ & 0,17 \\
Iso-butyric acid (mM) & $0,29^{\mathrm{b}}$ & $0,21^{\mathrm{ab}}$ & $0,14^{\mathrm{ab}}$ & $0,15^{\mathrm{ab}}$ & $0,04^{\mathrm{a}}$ & $0,04^{\mathrm{a}}$ & 0,06 \\
N-butyric acid (mM) & $0,29^{\mathrm{ab}}$ & $0,55^{\mathrm{b}}$ & $0,18^{\mathrm{a}}$ & $0,05^{\mathrm{a}}$ & $0,06^{\mathrm{a}}$ & $0,13^{\mathrm{a}}$ & 0,09 \\
Iso-valeric acid (mM) & $0,28^{\mathrm{b}}$ & $0,08^{\mathrm{a}}$ & $0,01^{\mathrm{a}}$ & $0,11^{\mathrm{a}}$ & $0,06^{\mathrm{a}}$ & $0,07^{\mathrm{a}}$ & 0,06 \\
N-valeric acid (mM) & $0,06^{\mathrm{a}}$ & $0,08^{\mathrm{a}}$ & $0,06^{\mathrm{a}}$ & $0,03^{\mathrm{a}}$ & $0,04^{\mathrm{a}}$ & $0,04^{\mathrm{a}}$ & 0,02
\end{tabular}


Noted:

1) $\mathrm{A}=100 \%$ corn straw with $20 \%$ pollard $+0 \%$ molasses supplementation; $\mathrm{B}=100 \%$ corn straw with $10 \%$ pollard $+10 \%$ molasses supplementation; $\mathrm{C}=100 \%$ corn straw $0 \%$ pollard $+20 \%$ molases; $\mathrm{D}=100 \%$ corn straw with $10 \%$ pollard $+0 \%$ molases supplementation; $\mathrm{E}=100 \%$ corn straw with $5 \%$ pollard $+5 \%$ molasses supplementation; $\mathrm{F}=100 \%$ corn straw with $0 \%$ pollard $+10 \%$ molases supplementation

2) Standard Error of the Treatment Means

3) Different alphabet on the same row show significantly different $(\mathrm{P}<0.05)$

The highest total VFA content in treatment B was $26,3750 \mathrm{mM}$ and $31,70 \%, 60,92 \%$, and $72,53 \%$ significantly $(\mathrm{P}<0,05)$ higher than treatment $\mathrm{A}, \mathrm{E}$, and $\mathrm{F}$, respectively, Whereas with treatment $\mathrm{C}$ and $\mathrm{D}$ respectively $2,13 \%$ and $12,92 \%$ not significant $(\mathrm{P}>0.05)$ higher (Table 4). When viewed as a whole, total VFA content in treatment $\mathrm{B}, \mathrm{C}$, and D is significantly higher than treatment $\mathrm{A}$, the high total VFA levels have no positive effect on the nutritional value of silage. Trisandewi et al. (2016) find that treatment A contained $16.19 \%$ crude proteinand and significantly $(\mathrm{P}<0.05)$ higher than other treatments and the crude fiber content of treatment $\mathrm{A}$ is $15.13 \%$ and significantly lower $(\mathrm{P}<0.05)$ than other treatments. High levels of VFA in silage $B, C$, and $\mathrm{D}$ are not useful because nitrogen is not available for microbial growth so that VFA is remaining or not utilized by microbes. This can be attributed to the high content of crude fiber in silage $\mathrm{B}, \mathrm{C}, \mathrm{D}, \mathrm{E}$, and $\mathrm{F}$ prove that fermentation does not work perfectly because of the low microbes in the silage treatment.

Dry matter and organic matter digestibility on treatment B supplemented with $10 \%$ pollard and $10 \%$ molases is the highest $(\mathrm{P}<0.05)$ among all treatments. This occurs because the silage of corn straw on treatment B contains pollard and molasses additives where pollard and molasses are microbes nutrients. Pollard as an energy and nitrogen source and molasses as energy sources. Energy and nitrogen content in pollard and molasses for microbial growth, so could produce enzymes for in-vitro fermentation. Increasing degradation by enzymes could increase dry matter digestibility. This also occurs in silage treatment $\mathrm{E}$ with $5 \%$ pollard and $5 \%$ molasses additive so that the yield ofdry matter digestibility in treatment $\mathrm{E}$ is slightly lower than treatment B but not significantly different $(\mathrm{P}>0.05)$.

Table.2: Dry matter and organic matter digestibility of corn straw silage

\begin{tabular}{lccccccc}
\hline \multirow{2}{*}{ Variables } & \multicolumn{5}{c}{ Treatments $^{\mathbf{1})}$} & \multicolumn{2}{c}{ SEM $^{\mathbf{2}}$} \\
\cline { 2 - 6 } & $\mathbf{A}$ & $\mathbf{B}$ & $\mathbf{C}$ & $\mathbf{D}$ & $\mathbf{E}$ & $\mathbf{F}$ & \\
\hline Dry matter digestibility (\%) & $54,87^{\mathrm{ab} 3)}$ & $62,77^{\mathrm{d}}$ & $51,32^{\mathrm{a}}$ & $57,37^{\mathrm{bc}}$ & $61,35^{\mathrm{cd}}$ & $56,66^{\mathrm{ab}}$ & 1,49 \\
Organic matter digestibility (\%) & $56,08^{\mathrm{a}}$ & $64,66^{\mathrm{c}}$ & $52,52^{\mathrm{a}}$ & $58,50^{\mathrm{ab}}$ & $62,33^{\mathrm{bc}}$ & $57,73^{\mathrm{ab}}$ & 1,87 \\
\hline
\end{tabular}

Noted:

1) $\mathrm{A}=100 \%$ corn straw with $20 \%$ pollard $+0 \%$ molasses supplementation; $\mathrm{B}=100 \%$ corn straw with $10 \%$ pollard $+10 \%$ molasses supplementation; $\mathrm{C}=100 \%$ corn straw $0 \%$ pollard $+20 \%$ molases; $\mathrm{D}=100 \%$ corn straw with $10 \%$ pollard $+0 \%$ molases supplementation; $\mathrm{E}=100 \%$ corn straw with $5 \%$ pollard $+5 \%$ molasses supplementation; $\mathrm{F}=100 \%$ corn straw with $0 \%$ pollard $+10 \%$ molases supplementation

2) Standard Error of the Treatment Means

3) Different alphabet on the same row show significantly different $(\mathrm{P}<0.05)$

Organic matter and dry matter digestibility have the same tendency where organic matter digestibility on additives with combination of pollard and molasses shows highest percentage both in $20 \%$ and $10 \%$ adiditive. Organic matter digestibility with $20 \%$ additive was obtained on treatment B while with additive $10 \%$ on treatment $\mathrm{E}$. It showed that addition of singularly additive is not good enough because microbes require nitrogen from protein degradable and energy (VFA) from soluble carbohydrate fermentation, so that the addition of pollard and molasses will be able to meet the needs of microbes for protein and energy.

\section{CONCLUSSION}

Based on results and discussion, it can be concluded that corn straw silage with combination of $10 \%$ pollard and $10 \%$ molasses supplementation or additives provides better results on $\mathrm{pH}$, total VFA, and dry matter and organic matter digestibility because rumen microbes require energy and proteins that contained in pollard and molasses additives. 


\section{ACKNOWLEDGEMENTS}

The researchers would like to thank to Directorate of Research and Community Service, Directorate General of Empowerment Research and Development, The Ministry of Technology Research and Higher Education the Republic of Indonesia for the fund, so this study can be completed until publication,

\section{REFERENCES}

[1] Bahri, S. (2012). Respon Silase Ransum Komplit Berbasis Jerami Jagung Sebagai Pakan Penggemukan Sapi Bali. Laporan Hasil Penelitian Dasar Keilmuan. Jurusan Peternakan Fakultas IlmuIlmu Pertanian Universitas Negeri Gorontalo.

[2] BPTP Sumatera Barat. (2011). Teknologi Pembuatan Silase Jagung untuk Pakan Sapi Potong. Badan Litbang Pertanian Kementerian Pertanian Republik Indonesia. Sumber: http//sumbar.litbang.pertanian.go.id. Diakses 15 Maret 2015.

[3] Food and Agriculture Organization of United Nation and USAID. (-). Silage Making For Small Scale Farmers Sorce: http://pdf.usaid.gov/pdf_docs/PNADQ897.pdf. Acces: May 12017.

[4] Hidayat, N dan Indrasanti, D. 2011. Kajian Metode Modified Atmosfir dalam Silo dan Penggunaan Berbagai Additif Pada Pembuatan Silase Rumput Gajah. Laporan Penelitian. Fakultas Peternakan. Unsoed. Purwokerto.

[5] Kushartono, B. and N. Iriani. (2003). Prospek Pengembangan Tanaman Jagung sebagai Sumber Hijauan Pakan Ternak. Prosiding Temu Teknis Fungsional Non Peneliti. halm 26-31.

[6] Retnani Y., L. Herawati, W. Widiarti, and E. Indahwati. (2009). Uji Sifat Fisik dan Palatabilitas Biskuit Limbah Tanaman Jagung sebagai Substitusi Sumber Serat Untuk Domba. Buletin Peternakan Vol. 33(3): 162-169.

[7] Steel, R. G. D., and J. H. Torrie. (1991). Prinsip dan Posedur Statistik. Suatu Pendekatan Biometrik. Edisi Kedua. Alih bahasa B. Sumantri. Jakarta. Gramedia.

[8] Trisnadewi, A. A. A. S., I G. L. O. Cakra., dan I W Suarna. (2017). Kandungan Nutrisi Silase Jerami Jagung Melalui Fermentasi Pollard Dan Molases. Majalah Ilmiah Peternakan Vol. 20(2): 55-59. Source: https://ojs.unud.ac.id/index.php/mip/article/view/322 17.

[9] University of Wisconsin, Division of Cooperative Extension. (2017). Corn Agronomy Wisconsin. Source: http://corn.agronomy.wisc.edu/Silage/S005.aspx. Cited May $1^{\text {st }} 2017$ 